\title{
北太平洋および鳥島のクロアシアホウドリの現状と保全
}

林 京一*・小城 春 雄*・鶴見みや古**・佐 藤 文 男**

\section{Present Status and Conservation of Black-footed Albatross Population in the North Pacific and on Torishima}

\author{
Kyoichi Hayashi*, Haruo Ogi*, Miyako Tsurumi** \\ and Fumio Sato**
}

\begin{abstract}
The Black-footed Albatross (Diomedea nigripes) now breeds on eleven islands in the eastern North Pacific and on five islands in the western North Pacific. The breeding population of the eastern North Pacific is slightly declining, but that of the western North Pacific is increasing. The total population in the North Pacific is estimated to be 200,000, of which 50,000 are breeding birds. This population size is very small compared with the congener Laysan Albatross (D. immutabilis), which has a total population of 2,500,000 birds. On Torishima, which has the largest breeding population of Black-footed Albatrosses in the western North Pacific, the Black-foots have increased in number, since a new colony was built on the island during the $1988 / 89$ breeding season. The numbers of fledged chicks in each breeding season were 1 in 1988/89, 5 in 1989/90, 84 in $1992 / 93,55$ in 1993/94, 125 in 1994/95, and 158 in 1995/96. In addition to the conservation of Short-tailed Albatrosses (D. albatrus), now successfully established on Torishima, multi-faceted protective programs are also planned for other breeding seabirds of this island. The programs should include such projects as: re-establishment of colonies of the Laysan Albatross and Tristram's Storm-Petrel (Oceanodroma tristrami), elimination of introduced animals, vegetation improvement, control of soil erosion at seabird nesting sites, and establishing a protected sea area around the island.
\end{abstract}

Key words: Black-footed Albatross, North Pacific, Torishima, Breeding population, Island conservation.

キーワード：クロアシアホウドリ, 北太平洋, 鳥島, 繁殖個体群, 繁殖 島の保全.

クロアシアホゥドリ (Diomedea nigripes) は北太平洋だけに生息し, 主に亜熱帯域の島嶼で 10 月より翌年の 5 月までの間繁殖し, その他の期間は外洋域で生活する大型海鳥である。北太

\footnotetext{
Received 11 April 1997, Revised 7 July 1997, Accepted 9 August 1997.

* 北海道大学水産学部, 干041 北海道函館市港町 3-1-1

** 財団法人山階鳥類研究所, 干270-11 千葉県我孫子市高野山 115

* Faculty of Fisheries, Hokkaido University, Minatocho 3-1-1, Hakodate, Hokkaido, 041 Japan.

** Yamashina Institute for Ornithology, Konoyama 115, Abiko, Chiba, 270-11 Japan.
} 
平洋東部で現在クロアシアホウドリが繁殖しているのは，八ワイ諸島の 9 島 (Nihoa, Necker, French Frigate Schoals, Laysan, Lisianski, Pearl and Hermes Reef, Midway, Kure, Kaula), そし て繁殖が推測されるが確認されていない2島 (Niihau，Lehua) である (Gould \& McDermon 1993)。繁殖地の消滅した島は Wake I., Johnston Atoll, Taongi Atoll の3つである (McDermon \& Morgan 1993)。一方, 北太平洋西部での現在の繁殖地は, わが国の尖閣諸島の北小島と南小 島（池原・下謝名 1971, 池原・阿部 1980, NHK 沖縄 1991）之黄尾嶼（河野私信）, 伊豆諸島 の鳥島, そして小笠原諸島の聟島等の 5 つである (Hasegawa 1982)。なお, 硫黄列島の硫黄島, 南鳥島 (Marcus I.) 等の繁殖地は消滅した（清棲 1980, McDermon \& Morgan 1993)。また台湾 の南西沖の膨湖諸島, そして南東沖の蘭嶼では, 過去に繁殖の可能性があったが現在では全く 見られない(顔 1979)。

クロアシアホウドリの世界の全生息数は 20 万羽, 毎年繁殖に参加するつがい数は 5 万と推 定されている (McDermon \& Morgan 1993)。1980 年代初期におけるわが国の鳥島, 南小島, 聟 島で繁殖しているつがい数は総計約 700 程であった (Hasegawa 1984)。このうち鳥島では, 約 500 つがいが繁殖していた (Hasegawa 1982)。最近の鳥島での繁殖つがい数は年々増加の傾向 にあり，1996 年 5 月の調査結果では 700-750つがいが繁殖している (佐藤 未発表記録)。一方 ハワイ諸島の French Frigate Schoals (3,911つがい), Laysan I. (14,000-21,000つがい), Midway I. (6,500-7,500つがい) 等の北太平洋東部のクロアシアホウドリの繁殖個体群は世界 の全繁殖鳥数の 67\% を占めているものの, 前二島では減少傾向にある (McDermon \& Morgan 1993)。クロアシアホウドリの全生息数は 20 万羽と推定されているが, クロアシアホゥドリと ほぼ同所的に繁殖しているコアホウドリ (Diomedea immutabilis) の全生息数 250 万羽と比較す ると 12.5 分の 1 と著しく少ない。クロアシアホウドリの営巣地は, 主に海岸線に近い砂浜, 砂 碟地, 裸地や斜面の下部に形成される, そしてコアホウドリの営巣地は海岸線より離れた灌木 が疎らに生えた草地斜面に多く形成される (Fisher 1972)。19 世紀後半から 20 世紀前半にかけ て活発に行われたアホウドリ類の羽毛採集時には, クロアシアホウドリの営巣地は, 上陸して きた採集者により捕獲しやすい為に短期間内に徹底的に破壊されたと考えられる (Fisher 1949)。このためにアホウドリ類の捕獲が禁止されて以後も, クロアシアホウドリの資源回復が コアホゥドリよりも著しく遅れているのであろう。恐らく，人間が大規模にアホウドリ類を捕 獲する以前には，クロアシアホウドリは現在以上に多数生息していたのであろう。以上の背景 からも, クロアシアホウドリの種個体群回復のための対策は, 各繁殖地において今後も注意深 く進める必要がある。

鳥島は東京の南約 $580 \mathrm{~km}$ に位置する周囲約 $8.5 \mathrm{~km}$ の無人の火山島である。現在のクロアシ アホゥドリの営巣場所は島の南東側の燕崎之西側の初寝崎の 2 ヶ所である。過去の生息数に関 しての記録は清棲 (1980) および渡部 (1963) によれば以下の如くである, 1929 年 2 月：生息確 認, 1932 年 4 月：約 200 羽, 1933 年 4 月：数羽, 1956 年 1, 3 月：成鳥 $35-40$ 羽, 1957 年 3 月： 成鳥 26 羽, 雛 6 羽, 1958 年 4 月：成鳥 10-12 羽, 睢 8 羽, 1958 年 12 月-1959 年 4 月：成鳥 20 羽, 雛 11 羽, 1959 年 12 月-1960 年 2 月：成鳥 34 羽, 雛 13 羽, 1961 年 2, 4 月：成鳥 42 羽, 雛 19 羽, 1962 年 2 月：成鳥 48 羽, 雛 18 羽, 1963 年 12 月：49 羽 20 卵。すなわち, 1932 年に 200 羽であったが，1933-1955 年の間は調查がないので詳細は不明であるが恐らく減少傾向に あったのであろう, 1956 年以降は増加傾向に転じたらしくし, 1963 年には約 50 羽となった 
(清棲 1973)。その後の 1977 年 3 月には, 燕崎で 126 羽の雛が確認された (Hasegawa 1978)。な お， 1929 年 2 月には, クロアシアホウドリは燕崎の他に初寝崎や兵庫浦（鳥島の北西部）の旧 奥山村近辺等の海岸に面した崖上の砂磁地でも営巣していた（山階 1931）。人間との接触のな い時代においては, クロアシアホゥドリは鳥島の海岸に近い至る所の砂磷地や斜面下部の草地 で多数繁殖していたのであろう。

燕崎の繁殖地は, 人間の接近が島の他の繁殖場所と比較して困難なために, クロアシアホウ ドリの営巣地としての利用が一時の中断はあったあのの維持されたのであろう。上記生息数の 記録で 1945 年（終戦年）以降は全て燕崎に唯一存在した営巣地におけるものである。藤澤 (1967) による 1961-1965 年の間の記録写真によれば, クロアシアホウドリの繁殖地は燕崎だけ に限定され，かつ営巣場所は海岸に近い砂碟地やラセイタソウ (Boehmeria biloba) とイソギク (Crysanthemum pacificum) が疎らに生えている斜面の下部に限定されていた。

初寝崎のクロアシアホゥドリの繁殖地の形成過程は, 1981 年 3 月に初めて 31 羽が飛来して お互いに求愛行動を始めた (Hasegawa 1982)。その後, 毎繁殖期間に訪れるようになり, 198889 年の繁殖期に初めて 1 羽の㮲が巣立った, そして続く $1989-90$ 年の繁殖期には 5 羽の雊が観 察された（環境庁 1990）。

初寝崎の单立ち直前の雛数は, 1993 年 5 月は 55 羽（山階鳥類研究所 1994）, 1994 年 5 月は 84 羽, 1995 年 5 月は 125 羽, 1996 年 5 月は 158 羽であった。これらの年別の雊の増加傾向から みても, 初寝崎のクロアシアホゥドリの営巣数は今後も増加傾向にあると考えられ, 継続した 調査が望まれる。一方, 1994 年 5 月の单立ち直前の雛の平均体重について初寝崎と燕崎を比較 すると有意差は認められなかった。1995 年 5 月では燕崎に比べ初寝崎の雛の方が平均で $200 \mathrm{~g}$ 重かった (Table 1)。クロアシアホウドリの雊の体重は 5 月中旬に最大となる。その後, 移動, 羽ばたきの練習, 成鳥羽への換羽等によるエネルギー消費は増大するにも拘わらず給䭒回数が 減るために雊の体重は巣立ちまで減少する (Rice \& Kenyon 1962, Fisher 1967)。このことから 1995 年 5 月では初寝崎の方が燕崎に比べ巣立ちが遅いことが示唆された。これは Ogi et al.

Table 1. Total number and body weight of Black-footed Albatross chicks on Torishima in 1994, 1995, and 1996. Significant difference between average body weights was only observed between Hatsune-zaki and Tsubame-zaki in $1995(F=2.917,0.01<P<0.05$; Cochran-Cox $t=2.254$, $0.01<P<0.05)$.

\begin{tabular}{lccc}
\hline \hline \multicolumn{1}{c}{ Nesting colony } & Hatsune-zaki & Tsubame-zaki & Total \\
\hline 20-22, May 1994 & & & \\
Total No. chicks & 84 & ca. $300-350$ & ca. $384-434$ \\
Body weight $(\mathrm{g}) \pm \mathrm{SD}$ & $3183 \pm 452$ & $3271 \pm 441$ & $3203 \pm 449$ \\
& $(\mathrm{n}=84)$ & $(\mathrm{n}=24)$ & $(\mathrm{n}=108)$ \\
\hline 19-21, May 1995 & 125 & 385 & 510 \\
Total No. chicks & $3466 \pm 437$ & $3265 \pm 256$ & $3400 \pm 397$ \\
Body weight $(\mathrm{g}) \pm \mathrm{SD}$ & $(\mathrm{n}=41)$ & $(\mathrm{n}=20)$ & $(\mathrm{n}=61)$ \\
& & & 614 \\
& 158 & no data & no data \\
\hline 16-20, May 1996 & no data & &
\end{tabular}


(1994) の燕崎よりも初寝崎の方が繁殖開始が若干遅いという結果と一致している。1994 年 5 月の両営巣地における雊間の平均体重に有意差が見出せなかったのは, 恐らく初寝崎の㮲倠の体 重がまだ最大に達する直前であったのに対し燕崎の雊は最大以後の体重減少期に相当していた ため, 生育段階に差はあったが体重は近似していたのであろう。なお，1994 年と 1995 年の雊の 平均体重を比較すると 1995 年の方が約 $200 \mathrm{~g}$ 重かったが，有意差は認められなかった。

鳥島には 1915 年前後にコアホウドリが数羽飛来して繁殖を始め, その繁殖は 1924 年, 1930 年, 1932 年に確認された（清棲 1980)。このうち，1930 年 2 月には 150 羽が確認された。また, 1929 年 2 月にはコアホゥドリが約 50 羽北西側の斜面で繁殖していた（山階 1931）。現在でもコ アホゥドリは, 毎年鳥島のアホウドリ類の繁殖地に 1 2 羽が稀に飛来して短時間休んでいる ことがあるため (佐藤 未発表記録)，デコイや音声による誘致努力をすれば繁殖地の再興が可 能であろう。

鳥島のアホゥドリ (Diomedea albatrus) とクロアシアホウドリの繁殖数が年々増加傾向にあ ることは, わが国の他の外洋性海鳥種の各地における繁殖個体数が概ね減少傾向にある背景か らも，極めて注目すべき事実である。鳥島のアホウドリ類の個体群回復にとって如何なる要因 が寄与しているのかを, 継続的かつ総合的に調査した結果は, 他の場所での海鳥保護対策に資 する面が多い。現在, 鳥島においては絶滅危惧種であり, かつ『特別天然記念物』であるアホ ウドリだけに関した保護対策が長谷川博氏 (東邦大学), 山階鳥類研究所, 東京都, 環境庁, 文 化庁等の努力で為され成果を挙げてきた。今後は, アホウドリの対策は勿論のこと, クロアシ アホウドリの継続的な調查, およびコアホゥドリの誘致対策, さらには現在鳥島では絶隇した とされているオーストンウミッバメ (Oceanodroma tristrami)(Hasegawa 1978) の繁殖地復元等 を包含した, 往時の海鳥群集を再構築する方向で保護対策が行われるべきである。その他の海 鳥類の生息環境整備対策として, クマネズミ (Rattus rattus) の駆除, ウイルスあるいは遺伝子 劣化のため矮小化したと考えられているハチジョウススキ (Miscanthus condensatus) (Hasegawa 1978) の治療, 繁殖地における土砂流出防止工事, 繁殖期間中は島よりある一定距離まで の海域を保護海面と設定して漁業活動や船舶の航行禁止等総合的な対策を今後は行うべきであ る。

本報を作成するに当たり, 琉球列島のクロアシアホウドリの情報を御教示下さった河野裕美 氏 (東海大学), 御批判を下さった百瀬邦和氏 (山階鳥類研究所), 御批判並びに英文校閲を睗っ た黒田長久博士（山階鳥類研究所）および John Bower 博士（北海道大学）等の諸氏に対して心 よりお礼申し上げる。

\section{引用文献}

Fisher, H. I. 1949. Populations of birds on Midway and the man-made factors affecting them. Pacific Sci. 3: 103-110.

Fisher, H. I. 1967. Body weights in Laysan Albatrosses Diomedea immutabilis. Ibis 109: 373-382.

Fisher, H. I. 1972. Sympatry of Laysan and Black-footed Albatrosses. Auk 89: 381-402.

藤澤 格 1967. アホウドリ Diomedea-albatrus. 刀江書院, 東京.

Gould, P. \& McDermon, D. 1993. Black-footed Albatross Diomedea nigripes Audubon, 1849. In: Gales, R. (ed.), Co-operative mechanisms for the conservation of albatross. Australian Nature Conservation Agency. Australia, pp. 35-41.

Hasegawa, H. 1978. Recent observations of the Short-tailed Albatross, Diomedea albatrus, on Torishima. Misc. 
Rep. Yamashina Inst. Ornithol. 10: 58-69.

Hasegawa, H. 1982. The breeding status of the Short-tailed Albatross Diomedea albatrus, on Torishima, 1979/ 80-1980/81. J. Yamashina Inst. Ornithol. 14: 16-24.

Hasegawa, H. \& DeGange, A. R. 1982. The Short-tailed Albatross, Diomedea albatrus, its status, distribution and natural history. American Birds 36: 806-814.

Hasegawa, H. 1984. Status and conservation of seabirds in Japan, with special attention to the Short-tailed Albatross. In Status and Conservation of the World's Seabirds. eds. Croxall, J. P., P. G. H. Evans \& R. W. Schreiber pp. 487-500. ICBP Technical Publ. No. 2.

池原貞夫, 下謝名松栄 1971. 尖閣列島の陸生生物. 尖閣列島学術調査報告, 琉球大学. pp. 85-114.

池原貞夫, 阿部挀哉 1980. 陸上動物調査 (1)（主に陸上脊椎動物及び大型土壌動物). 尖閣諸島調査報告書 (学術調查編), 沖縄開発庁. 1-45.

環境庁 1990. 鳥島アホゥドリ繁殖地緊急保全対策調査報告書. $36 \mathrm{pp}$.

清棲幸保 1980. 日本鳥類大図鑑. 3, 講談社, 東京.

清棲幸保 1973. 野鳥の事典. 東京堂出版, 東京.

McDermond, D. K. \& Morgan, K. H. 1993. Status and conservation of North Pacific albatrosses. In: Vermeer, K., Briggs, K. T., Morgan, K. H. \& Siegel-Causey, D. (eds.), The status, ecology, and conservation of marine birds of the North Pacific. Spec. Publ. Canadian Wildlife Service. Canada, pp. 70-81.

*NHK 沖縄 1991. 六度目の訪問一動物学者の尖閣紀行一. ワンダーランド九州シリーズ.

Ogi, H., Sato, F., Mitamura, A., Baba, T. \& Oyama, H. 1994. A survey of Black-footed Albatross breeding colonies and chicks on Torishima, January 1994. J. Yamashina Inst. Ornithol. 26: 126-131.

Rice, D. W. \& Kenyon, K. W. 1962. Breeding cycles and behavior of Laysan and Black-footed Albatrosses. Auk 79: $517-567$.

渡部栄一 1963. 鳥島のあほうどり．南鳥島・鳥島の気象累年報および調查報告. 気象庁，東京. pp. 156168.

山階芳穈 1931. 鳥島紀行．鳥 7: 5-10.

山階鳥類研究所 1994. アホウドリの営巣地の分散技術の開発に関する研究報告書. 平成 5 年度環境庁委託 事業報告書.

顔 重威 (Yan, Chong wei) 1979. 台湾飛翔. 長松出版社, 台北.

* 放映テレビ番組 